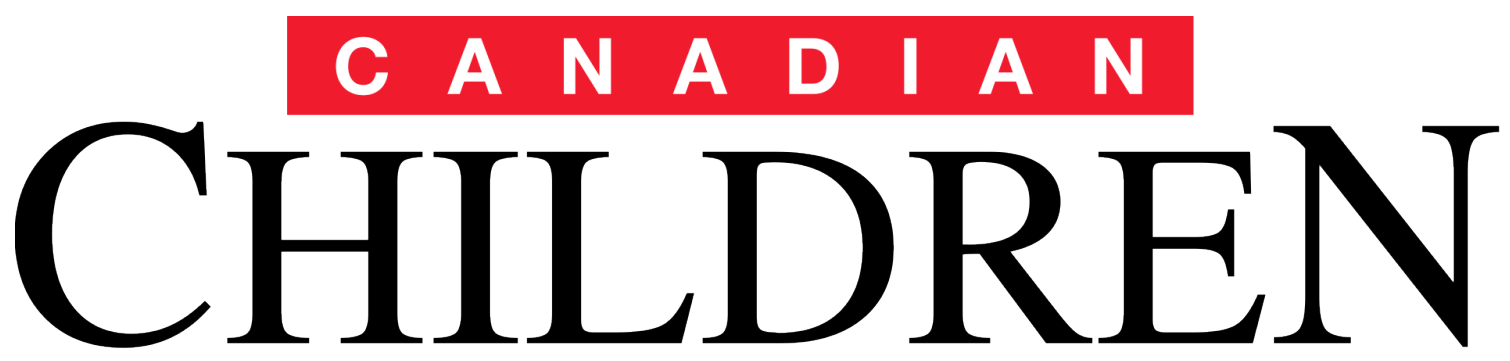

JOURNAL OF THE CANADIAN ASSOCIATION FOR YOUNG CHILDREN

Winter 2015/Hiver 2015

Vol. 40 No. 1

\title{
Pedagogical Narrations and Leadership in Early Childhood Education as Thinking in Moments of Not Knowing \\ By Iris Berger
}

\section{A N A D I A N}

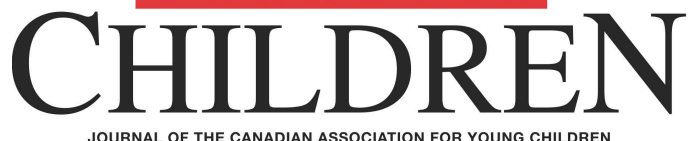

JOURNAL OF THE CANADIAN ASSOCIATION FOR YOUNG CHILDREN

Winter 2015/Hiver 2015

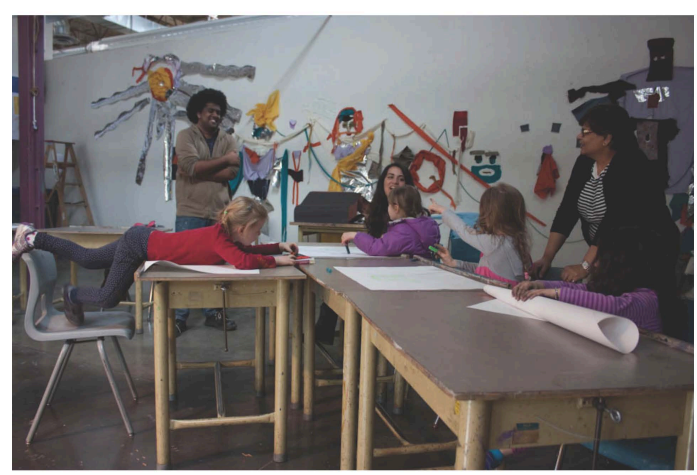

The Canadian Association
for Young Children
Editors:

Dr. Laurie Kocher, Douglas College, Coquitlam, British Columbia Dr. Veronica Pacini-Ketchabaw, University of Victoria, Victoria, British Columbia

Guest Editors, Special Issue: Professionalism in ECEC Dr. Rachel Langford, Dr. Jane Hewes, Sonya Hooper, and Monica Lysack

Publications Chairperson:

Dr. Iris Berger,

University of British Columbia,

Vancouver, British Columbia

Cover Photo:

Dr. Sylvia Kind

(C) 1996: The Canadian Association for Young Children ISSN: 0833-7519

Author Guidelines: visit www.cayc.ca

Published with support from the Social Sciences and Humanities Research Council of Canada

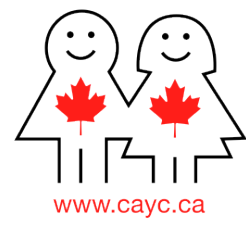




\title{
Canadian Children
}

\section{JOURNAL OF THE CANADIAN ASSOCIATION FOR YOUNG CHILDREN}

Volume 40 Number 12015 [page 130 to 147]

www.cayc.ca

\section{Pedagogical Narrations and Leadership in Early Childhood Education as Thinking in Moments of Not Knowing}

\section{by Iris Berger}

\begin{abstract}
Author's Bio
Iris Berger, EdD, has been involved in the field of early childhood education in British Columbia for over 15 years. She is currently a coordinator and a lecturer with the Institute for Early Childhood Education and Research (IECER) in the Faculty of Education, University of British Columbia. Her research interests include teachers' agency, educational judgment, pedagogical leadership, ethics, and the practice of pedagogical narrations. Email: berger.iris@gmail.com
\end{abstract}

\begin{abstract}
In this article, I draw from a recent research project that examined how a reconceptualized notion of leadership in early childhood education (ECE) is enacted through the practice of pedagogical narration. Pedagogical narration involves a process through which early childhood educators create and share narratives about significant pedagogical occurrences with children from their early childhood settings with the purpose of engaging others in critical dialogue where construction of children's identities and the values embedded in ECE practices are made visible and open for disputation and renewal. Here I present a particular dimension of leadership enactment that is associated with the practice of pedagogical narration, and I relate this leadership to thinking in moments of not knowing. By providing an example of how leadership was enacted, I wish to illuminate the potentiality of the practice of pedagogical narration to orient educators toward complexity and thinking that is triggered by encounters with unexpected pedagogical situations. Such encounters have the potential to initiate educational judgment that is inspired by events and not by following known rules and standards. They invite thinking beyond generalizations and clichés and they orient future (more) responsive and ethically rich pedagogical ventures in ECE contexts.
\end{abstract}


Pedagogical practices and relations in early childhood education can easily become sedimented in routinized ways of acting and responding, sinking into what the philosopher Hannah Arendt (1963/1977) called "habits of thoughtlessness." In this article I argue that the practice of pedagogical narration, especially when it is attentive to and dwells on unexpected events that unfold in early childhood contexts, opens up a space where new insights about the complexities of teaching and children's ways of being can emerge. These insights, made visible through the process of pedagogical narration, have the potential to orient the ECE community toward thinking that moves beyond generalizations and clichés, because being attentive to unexpected events necessitates creative thought and unprecedented pedagogical responses. Here I see the potential of pedagogical narration to contribute to a reconceptualized notion of leadership in early childhood education, in particular, through a dimension of leadership I call thinking in moments of not knowing.

Pedagogical narration is a term that we use in British Columbia to describe a process through which early childhood educators document (by means of photography, video or audio recording, and collection of children's creations) and then share narratives about significant pedagogical occurrences from their early childhood settings with the purpose of engaging others (children, colleagues, parents) in critical dialogue where assumptions about early childhood pedagogical practices and children's identities are made visible and open for disputation and renewal. The practice of pedagogical narrations has been adapted from similar pedagogical tools, such as pedagogical documentation (Rinaldi, 2006), practiced in the pre-primary schools of Reggio Emilia, and learning stories (Carr, 2001), a practice that is used in early childhood settings in New Zealand. Recently, practices such as pedagogical documentation, learning stories, and pedagogical narration have arisen, not only as innovative pedagogical practices, but also as a site for resisting universalized and taken-for-granted views of "doing" early childhood education (Carr, 2001; Dahlberg \& Moss, 2005; Rinaldi, 2006).

\section{The Study}

\section{Context and Purpose}

The urgency of investigating leadership in the early childhood arena rises due to the fact that the field of ECE is presently confronted with unprecedented political attention both locally and internationally (Langford, 2010; McTavish, 2012; Organisation for Economic Cooperation and Development, 2006). Over the last decade, national and provincial governments in a significant number of countries, including Canada, have created centralized early childhood curricula documents and have established closer structural relationships between early childhood and the formal education system. The changes that take place at the policy/political level raise new questions about the possibility and responsibility of early childhood educators to enact leadership by taking a

\section{Canadian Children}


stance and becoming active participants in change rather than "just observers of this moment in the field's evolution" (Goffin \& Washington, 2007, p. 3).

Yet leadership, when understood conventionally, has had troubled relations with the field of ECE. Traditional views of leadership, namely, forms of leadership that are associated with administrative approaches, hierarchical structures, and a position that is typically held by a male figure are deemed by early childhood educators as antithetical to the collaborative and relational "nature" of the early childhood profession (Hard, 2005; Rodd, 1997; Woodrow \& Busch, 2008). An additional challenge to leadership in ECE is linked with the gendered nature of the profession. Most persons working in early childhood are women (Muijs et al., 2004). Relatedly, the professional identity of the early childhood educator has been constructed on notions of "caring" and "niceness," rather than on taking a stance or articulating one's position in public (Fasoli, Scrivens, \& Woodrow, 2007; Grieshaber, 2001; Hard, 2005; Rodd, 1997). Therefore, I argue that there is a need to develop and investigate alternative frameworks for ECE leadership, frameworks that expand not only the notion of leadership but also the identities of the early childhood professional.

The study's purpose, then, was to explore the possibility of the practice of pedagogical narrations for reconstituting ECE educational leadership. More specifically, this research project focused on studying the leadership potential that the practice of pedagogical narration holds because it positions early childhood educators as narrators or storytellers who can instigate (with the narrations) public conversations that complicate and broaden the discussion about early education and the images of young children. The study also explored what new possibilities for leadership identities arise when early childhood educators provoke others to think and talk about narratives that relate significant pedagogical events from their ECE settings. The study is anchored in the belief that a different conceptualization of leadership produces different possibilities for action in the world (Mackler, 2008).

\section{Theoretical Framework}

Hannah Arendt's (1906-1975) mediation on political theory acted as a rich conceptual reservoir for this study, because Arendt associated political action with acts of storytelling or narration in the public sphere. It is important to note that, for Arendt, storytelling was not about self-expression or transmission of values and knowledge; rather, "storytelling was about telling a provocative story that stirs people to think what they are doing" (Disch, 1994). According to Arendt, stories, once they are told and made public, gain the potential to expand the web of human relations by revealing the plurality of perspectives on a common public matter. Thus, narratives illuminate the contingency and complexity of our human condition, and as such, they reinstate possibilities for renewal or change.

\section{Canadian Children}


From this premise, we can begin to imagine ECE leadership that is manifested in the willingness of the educator to speak and act, or to tell a provocative story in a public forum. Hence, in the study, acts of leadership were linked with early childhood educators taking on the position of narrators and initiators of dialogue and critical reflection about possible meanings of stories pertaining to significant events from children's lived experiences.

\section{Methods}

A view of leadership as associated with storytelling and dialogue entailed examining acts of leadership in relation to, and within, the context of communities. Therefore, I employed a qualitative multiple case study method (Stake, 2006). I studied how pedagogical narration and its leadership potential was enacted across four early childhood settings: preschool (private, part time, two educators), childcare (private, full day, a team of educators), StrongStart (public, drop in, single educator), and parent co-op (private, part time, single educator working with parents).

\section{Data Sources and Analysis}

Multiple data-gathering strategies were used; they included (a) observations of occasions when pedagogical narrations were shared with either children, colleagues, or parents, (b) interviews with six early childhood educators who acted as key participants about the practice of pedagogical narrations, and (c) samples of pedagogical narrations collected from each site. Data collection lasted for the period of a school year.

In the analysis process I used concepts from Arendt's political theory, especially those related to narration as political action, to deepen and complicate the meanings of themes identified in the data. The generative relation between the themes and Arendtian concepts helped me identify significant leadership events. These leadership events illuminated the potential of pedagogical narration for enacting leadership through reconstituting ECE as a public space, mitigating habits of thoughtlessness, and pluralizing the identities of children.

\section{Thinking and ECE Leadership}

In this article I focus on one dimension of the leadership enactment identified in the study: leadership enactment that is related to mitigating habits of thoughtlessness. To establish my argument, I begin by discussing the troubled relationships between the act of thinking and the traditional image of the early childhood educator. I continue by elaborating on Arendt's contention that thinking is intricately related to our responsibility to respond to what emerges as "new" and unprecedented, and I introduce her metaphor of "the wind of thought." I then explain how two themes that I identified in the datastriving for complexity and valuing surprise - are linked with Arendt's view of thinking and with a new way of conceptualizing ECE leadership. To ground my argument further, 
I present an example of leadership enactment from the childcare site, where Erin, one of the key participants, provoked her colleagues "to think what they are doing" by creating a pedagogical narration that illuminated the impossibility to know a child.

\section{The Changing Image of the Early Childhood Educator}

In the realm of ECE, a new image of the early childhood educator as a researcher and reflective thinker has emerged in the scholarly literature (Grieshaber \& Cannella, 2001; MacNaughton, 2003a; Moss, 2006; Nimmo \& Park, 2009), ECE research projects (MacNaughton, 2005; Pence \& Pacini-Ketchabaw, 2010), and, more recently, in ECE policy documents (see, for example, The BC Early Learning Framework, Government of British Columbia, 2008). With the introduction of critical theories into ECE pedagogical thought, a shift in the image of the early childhood educator has been advanced with the purpose of contesting traditional, dominant, and gendered images of early childhood educators. These traditional images (which still haunt the field) portrayed early childhood educators as substitute mothers who rely for their practice on "innate" and "natural" "motherly intuitions" (Moss, 2006). Viewed from this perspective, little attention, expectation, or recognition has been given to the intellectual engagement required on the part of educators who work with very young children (Dalli, 2001; Grieshaber, 2001; Moss, 2006; Nimmo \& Park, 2009).

Relatedly, early childhood educators have been positioned as consumers and implementers of external theories, especially theories of child development that have been cemented into ECE training programs and are required knowledge for ECE licensure (Langford, 2006, 2008). Recently, MacNaughton (2003b) and others (e.g., Cannella, 1997) have challenged the idea that there is an objective body of early childhood knowledge that educators can use to guide their practice. This critical position opened new paths for thinking about how early childhood educators can make meaningful contributions to understanding ECE by raising and responding to questions about their practice while creating new, more complex meanings for themselves and others. In discussing the teacher as a researcher, Rinaldi (2006) urges early childhood educators to become searchers of the meanings of teaching and of being a teacher. She defines research in practice as a generative force that mitigates a routinized way of existence through bringing newness and uniqueness to the daily pedagogical work.

Newly emerging images of early childhood educators as researchers and critical thinkers broaden and extend possibilities for educators to see themselves beyond those who apply theories and policies developed somewhere else. This study contributed and extended these emerging images for early childhood educators by arguing that the notion of the early childhood educator as a thinker can and should be linked with a reconceptualized notion of leadership in ECE. In particular, the study demonstrated that educators could stir in others "the wind of thought" with pedagogical narrations that engage with moments of not knowing.

\section{Canadian Children}




\section{Thinking with Arendt's Wind of Thought}

What begins as wonder ends in perplexity and thence leads back to wonder. How marvelous that men can perform courageous or just deeds even though they do not know, can give no account of, what courage and justice are.

$\sim$ Hannah Arendt (1978)

Thinking, critical understanding, and reflective judgment played an important part in Arendt's political theory. Two particular aspects of her reflections about thinking are central to this article: her insight about the danger of thoughtlessness and her insistence on the significance of the experience of thinking - as a critical and inventive activity - in moments of crisis in understanding, or, in what Arendt (1990) called moments of notknowing.

Arendt (1978) felt compelled to write about the activities of thinking as a response to her controversial yet insightful interpretation of the trial of Adolf Eichmann, one of the leading officers responsible for the extermination of Jewish communities during the Holocaust. As a reporter for The New York Times in 1963, Arendt covered Eichmann's trial. She characterized his actions as a manifestation of "the banality of evil" (Arendt, 1963/1977). In contrast with the line of argument that the Israeli persecutor put forth in the trial, namely, that Eichmann was a monstrous, evil man, Arendt, who found Eichmann to be a shallow, "ordinary" man, posited that it was Eichmann's inability to think, or his thoughtlessness, that enabled him to participate in atrocities of such magnitude. Arendt argued that Eichmann's line of defence that he was simply following orders and routine procedures, as well as his consistent use of cliché-ridden language, pointed to a phenomenon that is even more alarming than the crimes of a disturbed, cruel murderer. She postulated that the human capacity to act thoughtlessly (when one acts as a cog in a machine) is a phenomenon that is not only "normal" or "banal," but can also become prevalent under certain social and political conditions. Her shocking realization about the potential consequences of the habit of thoughtlessness propelled Arendt (1978) to wonder and write about the relation between the activity of thinking (the habit of examining whatever happens to pass or attract attention) and judgment (an ethical response-ability to whatever happens).

Relatedly, the concept of "understanding" accompanied Arendt's work since the rise of totalitarianism regimes. Arendt saw understanding as a complicated yet necessary, unending process that is "distinctive from correct information and scientific knowledge" (Arendt, 1994, p. 307). Most significantly, Arendt's own commitment to try to understand the phenomenon of totalitarianism and, more broadly, her commitment to the project of understanding "whatever happened" implied a particular relation with the world, a relation of responsibility for the world through a process of reconciliation with a reality that is always "coming out of order" (Arendt, 1994, p. 308). Therefore, we may 
say that Arendt insisted on our responsibility to understand an unknowable world, and while understanding produces "unequivocal results," it creates a kind of resourcefulness as it prepares us for judgment and action in moments of uncertainty.

The responsibility to try to understand as a process of reconciliation with and responsibility for the world depends on the activity of thinking. For Arendt, thinking, or the "wind of thought," emerges as a response to an encounter with an unexpected event or the new. Thinking is an activity that is demanded when we experience a crisis in understanding - "when the event we try to understand deprived us of our traditional ways of understanding" (Arendt, 1994, p. 310) and our "categories and standards of judgment collapse" (p. 313). This necessitates what Arendt called thinking "without a banister" or "beyond what we know," as Bernstein (2000, p. 283) put it. In other words, when we give our thinking attention to events that disrupt our understanding, we are confronted with not knowing and we are propelled to seek the meaning of the phenomena and events in their uniqueness and contingency; it is in these moments that thinking gains its ethical and political significance (Bernstein, 2000, p. 289), because we do not subsume the particular event under a general rule, and thus we create a possibility for a new understanding. Moreover, Arendt (1978) argues that thinking is self-destructive: once we think we have grasped something, it dissolves again into perplexities and, as Arendt suggests, the best we can do with these perplexities is to "share them with each other" (Arendt, 1978, p. 175). Thinking is thus a kind of an awakening that orients us back to the world, toward others, and thus it highlights our interdependency.

Thinking with Arendt's thinking helped me to theorize how and why the practice of pedagogical narration has potential for reconceptualizing ECE leadership. More specifically, in what follows, I argue that leadership emerged when educators' experience of not knowing was conceived, not as a failure but as an opportunity to be stirred by the "wind of thought" and to share "perplexities" with others through pedagogical narratives. When moments of perplexity are offered to the community in the process of pedagogical narration, the community is "forced" to think about the unpredictable and contingent nature of our lives and to find together new meanings, new realities, and new relationships in a world that, for the most part, desires control, predictability, and knowing.

\section{Pedagogical Narrations, Surprise, and Complexity}

\section{Striving for Complexity}

Pedagogical narrations are distinguished from traditional child observation and representation methods that sought to produce an objective account of children's behaviour, development, and learning (Dahlberg, Moss, \& Pence, 2007). In contrast, pedagogical narrations, as an alternative approach to child's observation, do not pretend

to describe reality or the child objectively. The practice of pedagogical narration involves 
complex interpretive work on the part of the educator and her community. While the practice of pedagogical narration creates fertile conditions for thinking and complexity, it also burdens educators with the responsibility to make choices about both the content (what to document) and process (how to interpret) of the pedagogical narration (Dahlberg et al., 2007). As such, it has ethically laden implications.

Being aware of the demands that pedagogical narrations make as a practice situated within interpretative and emergentist framework, the participating educators in the study talked about the challenges they encountered while attempting to deepen and broaden their interpretive repertoire about the documented events. In the interviews, the educators emphasized how the practice of pedagogical narrations required a higher level of complexity as they moved from thinking about pedagogical narration as a mere descriptive account of what happened to a more interpretative framework.

For example, Karen, the key participant from the parent co-op site, discussed how her practice of pedagogical narration had changed from the first attempts, which included placing photos of children with little sticky notes under them on the classroom walls to engaging in extended processes of conversation for a number of months with children, parents, and colleagues about a documented event. Through these conversations, readings of contemporary ECE scholarly work, writing, and presenting narrations in public events, Karen's understanding of the possibilities of the practice of pedagogical narration widened when she began to see that pedagogical narrations could be part of a bigger political project that sought to shift traditional conceptions of childhood and education.

Across all sites, pedagogical narration was linked with the act of thinking. Erin, a key participant from the childcare site, also saw the process of creating a pedagogical narration as an opportunity to engage more deeply with her practice. For Erin, this desire for engaging with complexity in one's practice involved a demanding and yet exhilarating intellectual work, or, as Erin put it, "it is a process of real thinking about what it is that you are seeing [in the documented material]." Deep engagement with her practice through pedagogical narrations was important to Erin because, not unlike Arendt's concerns about the dangers of thoughtlessness and shallowness, Erin was concerned that "we are on automatic pilot all the time, we just move from A to B and you multi-task." Similarly, when I asked Camille, a key participant from the childcare site, how working with pedagogical narrations affected her, she said, "I am thinking about what I am doing and why I am doing that. Whereas before it was like, this is what we are doing, you get caught in the wheel and you are just going through the motion."

Despite the educators' passion for thinking and complexity, their comments also reflected the difficulty in responding to the demands that the practice of pedagogical narration presented. Laura, the key participant from the StrongStart site, expressed this powerfully:

\section{Canadian Children}


If you asked me a year ago about pedagogical narration I felt much more sure of myself, whereas now I have more questions and thoughts about the words I am using in my narration. 'What am I trying to say?' 'Who is the audience?' 'Am I reflecting on my own practice?'

Rather than taking Laura's comment negatively, I would like to suggest that this quote actually strengthens the argument that the practice of pedagogical narration acts as an ongoing provocation of thought.

\section{Valuing Surprise}

In relation to the educators' desire for complexity was the finding that rather than using pedagogical narrations for assessment or representation of children's development based on predefined outcomes, most of the pedagogical narration samples collected in the study were narratives that were initiated as a response to events that the educators chose to document because of their quality of surprise or unexpectedness and due to their capacity to evoke wonder and questions. By choosing to document unexpected events, the educators participating in this study opened up possibilities to think about education through what Osberg and Biesta (2008) call the "'logic' of emergence" (p. 313). From an "emergentist" (p. 313) conception of education, knowledge does not exist prior to our participatory actions, and every meaning that emerges in these actions can be understood as "uniquely new, something which has not been in the world before" (p. 313). More significantly, Osberg and Biesta argue that the logic of emergence also applies to human subjectivity. In other words, when the educational space is open to the emergence of unknown meanings, it also opens up possibilities for the unknown uniqueness of the child (and the educator) to emerge.

From this premise, ECE leadership was enacted when educators complicated the pedagogical scene in ways that kept open the possibility for the event of the emergence of meanings and identities. Leadership was also enacted when moments of crisis in understanding (which are abundant in educational contexts due to the unpredictability of learning and the messiness of classroom practice, as Osberg and Biesta emphasize) were made visible and foci for thought. Leadership, from this angle, is about making visible the unpredictability, creativity, and messiness of the lived experience in the classroom as a vibrant context for experimentation, rather than an attempt to mask or conceal them.

Within the context of this study, being intrigued and surprised by what children had done or said played a significant role in the practice of pedagogical narration and leadership enactment. The key participants in this study described their initial moment of decision to document an event as a response to something that took them by surprise. Moss (2006) argues that a view of the early childhood educator as researcher means that the educator "is open to, indeed welcomes, the unexpected, that which takes her by surprise and by so doing provokes new thought that requires valuing doubt and 
uncertainty" (p. 36). Connections between initiating pedagogical narrations and being surprised by children's actions and words were mentioned during the interviews across all sites. For example, this is how Laura, the key participant from the StrongStart site, described what prompted her to document an event:

I think in all of them [all the pedagogical narrations she had created] it's been - the child had said something and that is what put me into that space 'cause it made me pause and think something that is different, something that is intriguing for them to say that I wouldn't normally anticipate ... as well as where is this going to go? So that's where it seems to have been. I have found when children say something or I see them do something different, it puts me in the space of curiosity.

It is the connections that Laura and the other study participants made between being surprised and thinking that I want to emphasize here. Mackler (2010), inspired by Arendt, reminds us that "without unpredictability, there is no need to think" (p. 519). For Arendt, as we have seen, thinking is something that happens to us - it is stirred by the "wind of thinking" that arises when we encounter the unexpected (Arendt, 1978, pp. 174175). It is inaugurated in the moment when something new gains the possibility to come into the world and surprise us. Jerome Kohn (1990) explains this as follows:

What Arendt demands of everyone is, of course, nonspecialized, noncognitive thinking, stopping whatever we are doing to tell a story, for instance, in order to shed a circle of light on an incident, giving it a point of meaning, and remaining bound to it 'as a circle remains bound to its focus.' Such an incident is 'often ordinary and common and ... the common and the ordinary must remain our primary concern, the daily food of our thought - if only because it is from them that the uncommon and extraordinary emerge. (p. 118)

Seen from this angle, thinking cannot be anticipated; it needs a space where the unexpected, the surprise, is welcomed. It is here that a new possibility for leadership with pedagogical narrations emerges when the educator gains the possibility to engage her community in narratives about moments of surprise that make room for disrupting thinking-as-usual. In the following section, I describe how leadership was enacted when Erin, a key participant from the childcare site, "put wonder to work" as she initiated thinking-bound-to-an-event in the process of creating pedagogical narrations.

\section{"The Music of Childhood" and Leadership Enactment as Thinking in Moments of Not Knowing}

The pedagogical narration called "The Music of Childhood" focused on young children's unique relationships with sounds. It was initiated by Erin, one of the key 
participants from the childcare site. Erin was completely surprised and deeply moved when she accidentally observed Neal, a two-year-old boy, creating music through rhythmic movements on the childcare playground. To invent his melody, Neal used a shovel to create the sound of gravel patter on the plastic slide, which he then followed by a patterned stomping on the ground with his rubber boots. Counter to Erin's expectation that children respond to music or sound when it comes from the outside, Neal seemed to have created music from within, in complete silence. Because of this encounter with Neal, Erin began an extended process of research about how the toddlers at the childcare centre, but also human beings in general, interact with and respond to sounds. Rather than using a camera to record children's experiences, Erin and her colleagues used a tape recorder to capture sounds that the children encountered and responded to during the day, which they later listened to with the children in order to revisit the sound experiences. This process led to numerous new insights about the role that sounds play in young children's lives, which were collected into a pedagogical narration. But for Erin, the research was not only about sounds or the music of childhood.

Because the encounter with Neal's musicality was so profound for her, Erin talked about this narration as "an invitation to pause and look for meanings about everything." She became fascinated with "big" questions. In her reflection about Neal's music experience that was at the centre of the narration, and later during discussions with her colleagues, Erin brought up questions such as, "What is musicality" "Where does it come from?" "What drives us as creative human beings?" and "What are we doing and for what purpose?" By posing these big questions, Erin opened up a space for herself and her colleagues to think, and indeed profound insights about children and about themselves as educators emerged, especially during the team meeting Erin organized with the other teachers and the centre director to discuss "The Music of Childhood." During the educators' meeting about the narration, Erin shared with her colleagues that what she realized from her reflection about Neal's response to sound was that she did not (and probably cannot) know him. In Erin's words:

What do I know about Neal? What do I know about him? You never know what the child's potential is. And we think that we are doing one thing and they may be doing something completely different.

When Erin brought up this complex idea of the impossibility of knowing a child during the meeting with her team, Elana, an educator from the childcare site, was deeply moved by it, and she had a profound insight about our inability to fully know "who" the child is:

I wanted to say one more thing about the responsibility that, Erin, you mentioned. When we observe kids and we learn about them and we want to know when they are doing something, what does it actually mean? And

\section{Canadian Children}


Ifeel that we will never know, because at some point it is also so private. I mean, we are responsible for them, we have to take care of them, but they also have their inner world that we have to-of course it is important that we speak with them, and we ask them, we teach them how to communicate, but sometimes it's just things we will never know; it's mysterious, like all of us (laughs). It will always be a mystery. That's why in education we always change ... because we always try to get to this mystery point.

Within the space of suspense that the narration had created, Erin and the other educators at the childcare centre were granted an opportunity to experience a kind of not knowing, a break with established formulations about how educational responses should be enacted.

Biesta (2006) maintains that we are trapped in a way of thinking about education as a process through which we predefine what kind of human we want to "produce." $\mathrm{He}$ further argues that for education to be an ethical pursuit, we need to leave the question of what it means to be human "as a radically open question, a question that can only be answered - and has to be answered again and again" (p. 151, original emphasis); this means that we need to recognize that we cannot assume that we can fully grasp or know the child. Seeing education from this perspective entails that the "responsibility of the educator is a responsibility for what is to come, without knowledge of what is to come" (Biesta, 2006, p. 148). Biesta, inspired by Arendt, contends that moments of not knowing are crucial if we are to experience education as a political practice, because the experience of not knowing is what gives rise to "seeing" something - children, parents, educators, or a phenomenon - in different and unique ways, inaugurating plurality and multiplicity. Dahlberg and Moss (2005) similarly note that while pedagogy is constituted in relationships, within this relationship there is a paradox — on one hand, the welcoming and being together with the child, and on the other, holding a space for distinction "to enable the possibility of difference" (p. 93). The child becomes a "stranger," or "a newcomer," to use Arendt's term, and "not a known quantity through classifying systems and normative practices" (Dahlberg \& Moss, 2005, p. 93).

ECE scholar Bronwyn Davies (2010) writes about pedagogical documentation (a practice similar to pedagogical narration, as noted above) as a "practice of open listening" (p. 124) and a "creative engagement with the not-yet-known" (p. 120). According to Davies, the most challenging aspect of the practice of documentation is to sustain it as a force that "facilitates the emergence of the not-yet-known" (p. 124), because all too often pedagogical narration can become simply the "shaping" of something that the documenter/narrator had set out to document in advance. With her provocative questions, Erin challenged herself and her colleagues to meaningfully engage with open questions, such as, "What does it mean to respond to a child we cannot know?" and "How do we exist with children?" In doing so, Erin enacted leadership by inviting her colleagues to 
"stay alert" (Biesta, 2006, p. 151) and to see and listen to children, to each other, and to their practice in a new way. This "newness" was evident in the way that childcare teachers Sonam, Uyen, and Elana talked about how they all-of-a-sudden thought about children and sounds in a completely different way. Elana went as far as saying that now she understood sound "as a new language." But more profound was the educators' encounter with not knowing.

Arendt (1990), referring to Socrates, explains that when the statement "I know that I do not know" (p. 437) comes from a state of wonder (not expressed in terms of lack of scientific answers), it loses its dry negativity, because

it is from the actual experience of not-knowing, in which one of the basic aspects of the human condition on earth reveals itself, that the ultimate questions arise - not from the rationalized, demonstrable fact that there are things man does not know, which believers in progress hope to see fully amended one day, or which positivists may discard as irrelevant. In asking the ultimate, unanswerable questions, man establishes himself as a question-asking being. (p. 437)

Thus, awareness of the impossibility of knowing the child is not a failure. Erin took this realization seriously and articulated it beautifully. Rather than thinking about not knowing a child as a flaw in her ECE practice, she saw it as a motivation to come together and dialogue more about how we see children from our different points of view, asking,

What do we know? Are we just doing something exploratory, repeating it again and again? What do we really know? So the observation is a big part of it and the open-mindedness is a big part and the discussion among us, because we may see things in totally different eyes and this sharing of what you see and what I see is important, it's essential. And we might see it the next day all of us differently because something came up. So sometimes just talking about an issue creates a shift for something. I noticed that the shift sometimes happens after discussion and awareness. And you don't even know how to explain it.

I cannot imagine a more profound connection between the practice of pedagogical narration and leadership than the process that is articulated so eloquently in the quote above. It is precisely in the moment that we encounter not knowing that responsibility as understanding an unknowable world and an unknowable other is widened by inviting others to think with us in moments of crisis in understanding. In this way, understanding becomes "the other side of action" (Arendt, 1994, p. 321), because thinking holds the possibility to make a new beginning, to experience freedom, and to bring out the significance of the new (p. 320). 


\section{Discussion}

In this article, I proposed that to think about ECE leadership in relation to the practice of pedagogical narration means to think about leaders not as those who already know and impart knowledge to everyone else, but rather, as those who alert others to the necessity to think in moments of not knowing. The practice of pedagogical narration triggered in educators an attunement to unexpected events that punctured a hole in ordinary understanding, and thus required complex, interpretive response. While pedagogical narrations have a unique potential to mitigate thoughtlessness, the complexity of the response to an event hinges on the capacity to see its significance, to make it a material for stirring the wind of thought, and to take a courageous step into the unknown. Erin enacted leadership when her encounter with moments in which she experienced not knowing (such as the encounter with Neal's musicality) became a site for stirring the wind of thinking in others as a search for meaning and a creative disruptive understanding.

Moreover, by sharing her perplexities with others and by asking questions of meaning that were inspired by her engagement with pedagogical narrations, Erin invited others to reflect with her on the ethical significance of the unexpected events. In doing so, Erin awakened others to their responsibility for a world that we cannot know but nonetheless are moved to preserve by thoughtfully responding to the appearance of something new and surprising. Her understanding that each one of her colleagues has something valuable to contribute to our collective, albeit temporary, understanding meant that leadership became a process of widening and deepening, not of finding a single answer.

Rinaldi (2006), a pedagogical leader from Reggio Emilia, brings an additional dimension into the conversation about the unexpected. She discusses the moment of initiation of pedagogical documentation (or pedagogical narration) as noticing a gap between our expectations and the actual event, or between the inherent (known) meaning and the emerging (unknown) meaning. She conceptualizes this gap as freedom and refers to these moments as "moments of freedom." Rinaldi claims that freedom "lies in this space between the predictable and the unexpected" (p. 70).

I am intrigued by Rinaldi's provocative proposition that it is the experience of freedom that lies in the "gap between the expected and the unpredictable," because in the current neoliberal political climate, where more regulations are put in place for education and teachers (Davies \& Bansel, 2007), we need educational leadership for creating experiences of pedagogical freedom. I wonder if engagement with pedagogical narrations as encounters with not knowing may occasion this kind of thinking/freedom relation. 


\section{References}

Arendt, H. (1977). Eichmann in Jerusalem: A report on the banality of evil. New York, NY: Penguin Books. (Original work published in 1963)

Arendt, H. (1978). The life of the mind. Orlando, FL: Harcourt.

Arendt, H. (1990). Philosophy and politics. Social Researcher, 57(1), 73-103.

Arendt, H. (1994). Understanding and politics (The difficulties of understanding). In J. Kohn (Ed.), Hannah Arendt essays in understanding, 1930-1954: Formations, exile, and totalitarianism (pp. 307-327). New York, NY: Schocken Books. (Original work published in 1954)

Bernstein, R. J. (2000). Arendt on thinking. In D. Villa (Ed.), The Cambridge companion to Hannah Arendt (pp. 277-292). Cambridge, UK: Cambridge University Press.

Biesta, G. J. J. (2006). Beyond learning: Democratic education for a human future. Boulder, CO: Paradigm.

Cannella, G. S. (1997). Deconstructing early childhood education: Social justice and revolution. New York, NY: Peter Lang.

Carr, M. (2001). Assessment in early childhood settings: Learning stories. London, UK: Paul Chapman.

Dahlberg, G., \& Moss, P. (2005). Ethics and politics in early childhood education. London, UK: RoutledgeFalmer.

Dahlberg, G., Moss, P., \& Pence, A. (2007). Beyond quality in early childhood education and care: Languages of evaluation ( $2^{\text {nd }}$ ed.). London, UK: Routledge.

Dalli, C. (2001). Being an early childhood teacher: Images of professional practice and professional identity during the experience of starting childcare. Paper presented at the New Zealand Association for Research in Education annual conference, Christchurch, New Zealand, December 6-9, 2001. Retrieved from: http://www.nzabe.ac.nz/conferences/2001/pdf/01_thursday_pm/DrCarmenDallipa per.pdf

Davies, B. (2011). Open listening: Creative evolution in early childhood settings. International Journal of Early Childhood, 43(2), 119-132.

Davies, B., \& Bansel, P. (2007). Neoliberalism and education. International Journal of Qualitative Studies in Education, 20(3), 247-259. Special issue: Neoliberalism and education. doi: 10.1080/09518390701281751 
Disch, L. J. (1994). Hannah Arendt and the limits of philosophy. Ithaca, NY: Cornell University Press.

Fasoli, L., Scrivens, C., \& Woodrow C. (2007). Challenges for leadership in Aotearoa/New Zealand and Australia: Early childhood contexts. In L. KeesingStyles \& H. Hedges (Eds.), Theorising early childhood practice: Emerging dialogues (pp. 231-249). Mt. Victoria, Australia: Pademelon Press.

Goffin, G., \& Washington, V. (2007). Ready or not: Leadership choices in early care and education. New York, NY: Teachers College Press.

Government of British Columbia. (2008). British Columbia early learning framework. Retrieved from: http://www2.gov.bc.ca/gov/DownloadAsset?assetId=245C9B82FFF94171BB618 18A53F0674A\&filename=early learning framework.pdf

Government of British Columbia. (2009). British Columbia early learning framework: From theory to practice. Retrieved from: http://www2.gov.bc.ca/assets/gov/topic/57FDB4389CD0FB3F6EC9948B610A6 BA9/earlylearning/from theory to practice.pdf

Grieshaber, S. (2001). Advocacy and early childhood educators: Identity and cultural conflicts. In S. Grieshaber \& G. S. Cannella (Eds.), Embracing identities in early childhood education (pp. 60-72). New York, NY: Teachers College Press.

Grieshaber, S., \& Cannella, G. S. (Eds.). (2001). Embracing identities in early childhood education: Diversity and possibilities. New York, NY: Teachers College Press.

Hard, L. (2005). How is leadership understood and enacted within the field of early childhood education and care? EdD dissertation, Queensland University of Technology. Retrieved from: http://eprints.qut.edu.au/16213/

Kohn, J. (1990). Thinking/acting. Social Research, 57(1), 105-134.

Langford, R. (2006). Discourses of the good ECE in professional training: Reproducing marginality or working toward social change. International Journal of Educational Policy, Research, \& Practice: Reconceptualizing Childhood Studies, 7, 115-125.

Langford, R. (2008). Making a difference in the lives of young children: A critical analysis of pedagogical discourses for motivating young women to become early childhood educators. Canadian Journal of Education, 13(1), 78-101. 
Langford, R. (2010). Innovations in provincial early learning curriculum frameworks. Occasional Paper No. 24. Childcare Resource and Research Unit. Retrieved from: http://www.childcarecanada.org/sites/default/files/op24_0.pdf

Mackler, S. (2008). Hermeneutic leadership: Hannah Arendt and the importance of thinking what we are doing. In E. A. Samier \& A. G. Stanley (Eds.), Political approaches to educational administration and leadership (pp. 109-122). New York, NY: Routledge.

Mackler, S. (2010). And worldlessness, alas, is always a kind of barbarism: Hannah Arendt and the challenge of educating in worldless times. Teachers College Record, 112(2), 509-532.

MacNaughton, G. (2003a). Shaping early childhood: Learners, curriculum, and contexts. Maidenhead, UK: Open University Press.

MacNaughton, G. (2003b). The possibilities and challenges of "not knowing": Early childhood teachers' knowledge and thinking in uncertain time. In O. N. Saracho \& B. Spodek (Eds.), Studying teachers in early childhood settings (pp. 29-42). Charlotte, NC: Information Age.

MacNaughton, G. (2005). Doing Foucault in early childhood studies: Applying poststructural ideas. New York, NY: Routledge.

McTavish, M. (2012). Troubling government discourse on early learning websites: A critical analysis. Canadian Children, 37(2), 5-12.

Moss, P. (2006). Structures, understandings, and discourses: possibilities for reenvisioning the early childhood worker. Contemporary Issues in Early Childhood, 7(1), 30-41. doi: 10.2304/ciec.2006.7.1.30

Muijs, D., Aubrey, C., Harris, A., \& Briggs, M. (2004). How do they manage? A review of the research on leadership in early childhood. Journal of Early Childhood Research, 2(2), 157-160.

Nimmo J. W., \& Park, S. (2009). Engaging early childhood teachers in the thinking and practice of inquiry: Collaborative research mentorship as a tool for shifting teacher identity. Journal of Early Childhood Teacher Education, 30(2), 93-104.

Organisation for Economic Cooperation and Development. (2006). Starting strong II: Early childhood education and care. Retrieved from: http://www.oecd.org/newsroom/37425999.pdf

Osberg, D., \& Biesta, G. J. J. (2008). The emergent curriculum: navigating a complex course between unguided learning and planned enculturation. Journal of 
Curriculum Studies, 40(3), 313-328.

http://dx.doi.org/10.1080/00220270701610746

Pence, A., \& Pacini-Ketchabaw, V. (2010). Investigating quality in early childhood care and education policies and practices in Canada, in N. Yelland (Ed.), Contemporary perspectives on early childhood education (pp. 121-138). Berkshire, UK: Open University Press.

Rinaldi, C. (2006). In dialogue with Reggio Emilia. London, UK: Routledge.

Rodd, J. (1997). Learning to be leaders: Perceptions of early childhood professionals about leadership roles and responsibilities. Early Years, 18(1), 40-44.

Stake, R. E. (2006). Multiple case study analysis. New York, NY: Guilford Press.

Woodrow, C., \& Busch, G. (2008). Repositioning early childhood leadership as action and activism. European Early Childhood Education Research Journal, 16(1), 8393. 


\section{In this issue:}

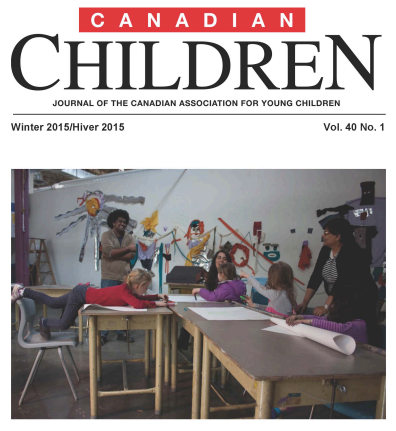

From the Editors' Desk Special Issue: Professionalism in ECEC Guest Editors: Dr. Rachel Langford, Dr. Jane Hewes, Sonya Hooper, and Monica Lysack

Beyond Professionalism: Interrogating the Idea and the Ideals by Randa Khattar and Karyn Callaghan

Negotiating Status: The Impact of Union Contracts on the Professional Role of RECEs in Ontario's Full-Day Kindergarten Program by Romona Gananatham

The Glass Ceiling Effect: Mediating Influences on Early Years Educators' Sense of Professionalism by Stefanie Tukonic and Debra Harwood

Enhancing Professionalism and Quality Through Director Training and Collegial Mentoring by Glory Ressler, Gillian Doherty, Tammy McCormick Ferguson, and Jonathan Lomotey

Authoring Professional Identities: Immigrant and Refugee Women's Experiences in an Early Childhood Teacher Education Program by Christine Massing

ECEs as Childcare Advocates: Examining the Scope of Childcare Advocacy Carried out by ECEs from the Perspective of Childcare Movement Actors in Ontario and Manitoba by Lyndsay Macdonald, Brooke Richardson, and Rachel Langford

From Child-Minders to Professionals: Insights From an Action Research Project on Prince Edward Island by Anna Baldacchino, Ray Doiron, Martha Gabriel, Alaina Roach O'Keefe, and Jessica McKenna

Pedagogical Narrations and Leadership in Early Childhood Education as Thinking in Moments of Not Knowing by Iris Berger

Find other articles from this issue at www.cayc.ca 